\title{
Membranous ventricular septal aneurysm - incidental discovery or supstrate for atypical chest discomfort? Case report
}

\author{
Rina Dalmatin ${ }^{\text {* }}$, \\ Teodora Zaninović \\ Jurjević \\ Luka Zaputovič ${ }^{2}$, \\ Alen Ružić \\ 'Pula General Hospital, Pula, \\ Croatia \\ ${ }^{2}$ University of Rijeka School of \\ Medicine, University Hospital \\ Centre Rijeka, Rijeka, Croatia
}

KEYWORDS: membranous interventricular septum, ventricular septal defect, stroke. CITATION: Cardiol Croat. 2017;12(4):159. | https://doi.org/10.15836/ccar2017.159

*ADDRESS FOR CORRESPONDENCE: Rina Dalmatin, Opća bolnica Pula, Zagrebačka 30, HR-52100 Pula, Croatia. Phone: +385-98-981-6480 / E-mail: rina.dalmatin@gmail.com

ORCID: Rina Dalmatin, http://orcid.org/0000-0003-1864-3314 • Teodora Zaninović Jurjević, http://orcid.org/0000-0001-8359-3910 Luka Zaputović, http://orcid.org/0000-0001-9415-9618 • Alen Ružić, http://orcid.org/0000-0001-5031-2975

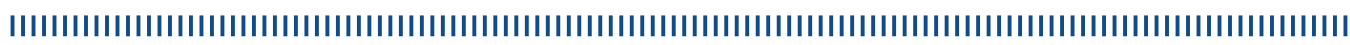

Introduction: Aneurysm of membranous interventricular septum is a rare cardiac abnormality and the prevalence is not known. It can be isolated but is usually associated with congenital heart disease, most often with ventricular septal defect. Most patients are asymptomatic but special caution should be taken in considering potential risk. ${ }^{1,2}$

Case report: 58 -year-old female is coming because she had chest pressure with discomfort in back, fatigue and weakness. The blood pressure was $140 / 80 \mathrm{mmHg}$, heart rate of 80 beats/min and no heart murmur were discovered by clinical examination. Electrocardiography showed sinus rhythm, normal axis and right bundle branch block. The transthoracic echocardiogram discovered and the transesophageal confirmed the aneurysm of the membranous intraventricular septum without septal defects, pathological flows or intracavital masses.

Conclusion: Aneurysm of membranous interventricular septum is occasional cardiac abnormality and the patients are often asymptomatic. Transthoracic echocardiography, transesophageal echocardiography, CT and MR imaging are methods of choice for diagnosis of VSA aneurysm. Patients with VSA have risk of thrombus formation and stroke, ventricular tachycardia and AV block, aortic insufficiency, intracardiac shunts, ruptures and endocarditis.
RECEIVED:

March 11, 2017

ACCEPTED:

April 6, 2017

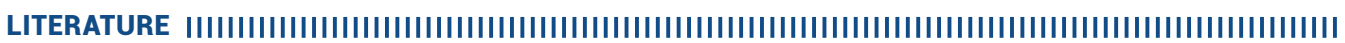

1. Naidu A, Ricketts M, Goela A, Shoemaker G, Li S. Incidental discovery of a membranous ventricular septal aneurysm in two dissimilar patients. Case Rep Cardiol. 2012;2012:324326. https://doi.org/10.1155/2012/324326

2. Carcano C, Kanne JP, Kirsch J. Interventricular membranous septal aneurysm: CT and MR manifestations. Insights Imaging. 2016 Feb;7(1):111-7. https://doi.org/10.1007/s13244-015-0456-3 